\title{
Effect of herbs and spices (plant extracts) on rumen microbial activities: a review
}

\section{Tolulope Oreoluwa Faniyi ${ }^{1}$, Micheal Kolawole Adewumi ${ }^{1}$, Enio Rosa Prates ${ }^{2 *}$, Ayansina 'Segun Ayangbenro'}

\author{
${ }^{I}$ Department of Animal science (Animal Production and Management) Faculty of Agriculture and Forestry, University of Ibadan, \\ Ibadan, Nigeria: tolulope.faniyi@ufrgs.br \\ ${ }^{2}$ Universidade Federal do Rio Grande do Sul, Faculdade de Agronomia, Departamento de Zootecnia, Porto Alegre, Rio Grande \\ do Sul, Brasil:00001450@ufrgs.br \\ ${ }^{3}$ Department of Microbiology, College of Biosciences, Federal University of Agriculture, Abeokuta, Ogun State, Nigeria \\ *Corresponding author
}

\begin{abstract}
Ruminant livestock are important sources of animal protein and calories, also are sources of global greenhouse emissions. There is increasing interest in evaluating the potential of natural antimicrobials such as plant extracts to modify rumen microbial fermentation due to reduction on the use of antibiotics in animal feeds and with ban on antibiotics in the Europe. These compounds are known to have an impact on rumen microbial metabolism by inducing changes in the fermentation conditions and also affecting ruminant productivity. The methods to effectively reduce methane production in the reticulo-rumen include processing of feeds, altering the diet, supplementation of unsaturated fatty acids, defaunation, supplementation of organic acids, halogenated compounds, ionophores, microbial feed additives (probiotics), plant extracts and their secondary metabolites. All these strategies to be validated in vivo studies in specific dose(s) to make it economically viable. This review aimed to reveal the impact of these natural plants extracts on rumen microorganisms. Plants normally contain a high to medium content of secondary compounds such as essential oil, saponins, organosulphur and tannins, which exert a specific effect against or favour rumen microorganism and reduce methane, leaving less or no distortion on the remaining rumen biomass. Their actions include direct action on microbial metabolism and deprivation of substrates for microbial growth. These plant extracts require more long term studies in vivo to determine their effectiveness in commercial systems. For sustainability, the feed additive would need to be effective over long periods of time, nontoxic for animals, the environment, the consumers and maybe standard use in animal feeds.
\end{abstract}

Keywords: Fermentation, methanogenesis, microbial population, rumen microorganism

\section{Introduction}

The digestive system of ruminant animals posses different microorganisms that have a great influence on the transformation of feed into endproducts (McSweeney \& Mackie, 2012). Thus, it is important to study microbial ecology of gastrointestinal tract of these ruminants, investigation of the organisms present (abundance and diversity), their activity and their relationship and the host (McSweeney \& Mackie, 2012).

Methane expelled by ruminants is on of the most important source of global warming, having a great impact on the environmental. Greenhouse gas emission, especially methane from ruminants, has been recognized as an important issue worldwide as it is a driver for global warming and climate change (Kim et al., 2012). It has been reported that livestock production and its by-products are responsible for at least 51 percent of global warming gases (Goodland \& Anhang, 2009). Gas emissions from the livestock sector are estimated at between 4.1 and 7.1 billion tonnes of carbon dioxide equivalents per year, equating to $15-24 \%$ of total global anthropogenic green house gas emissions (Wanapat et al., 2013). Ruminant 
nutritionists have examined or evaluated many substances such as essential oil, plant and plant extracts, plant secondary metabolites, etc... to in order to manipulate the rumen microbial ecosystem to reduce methane emission (Kim et al., 2012). Thus, from the aforementioned parameters there is need to search for more natural alternatives to modify/manipulate the rumen enviromethe need to identify feed additives to modify ruminal fermentation characteristics and increase the efficiency of feed utilization, and inhibiting the ruminal methanogenesis.

Microbial fermentation and physical breakdown during rumination are a combination of factors responsible for feed degradation in the rumen (Hart et al., 2008). Fermentation by microorganisms is carried out by a mixed population of bacteria and ciliate protozoa, together with smaller (Archae) and metabolically important population of anaerobic fungi (Dehority, 2010).

Non-therapeutic levels of antibiotics are usually included in the diet to increase feed efficiency and prevent disease in livestock production (Benchaar et al., 2008a, Zawadzki et al., 2011, Valero et al., 2014b). The use of antibiotics in livestock diet for disease prevention has been banned in the European Union because of the emergence of multi-drug resistant bacteria that may pose health challenge (Russell \& Houlihan, 2003). Restrictions placed on the usage of this antibiotics and consumers health concern on the use of antibiotics in animal feeds had increased interest in the exploration of alternatives to antibiotics in manipulating rumen fermentation (Yildiz et al., 2015, Tomkins et al., 2015). As a result, studies are concentrated on the use of substances such as probiotics, prebiotics, organic acids, enzymes and plant extracts (Geraci et al., 2012, Kim et al., 2012, Patra \& Saxena, 2010). Natural plants products are thus considered in this review as alternatives to antibiotics in manipulating rumen fermentation and their effects on rumen microbial population ( et al., 2016, Cruz et al., 2014, Valero et al., 2014a). Therefore, decreasing enteric methane production by ruminants without altering animal performance is desirable as way of reducing global green house gas emissions and as a strategy for improving feed conversion efficiency (Martin et al., 2010).
Murray et al. (1976) reported that rumen is the origin of the most enteric methane produced by ruminants. Anaerobic digestion of feed components in the rumen by microorganisms results in the production of volatile fatty acids, mainly acetate, propionate and butyrate (Martin et al., 2010). These volatile fatty acids are used by ruminants as energy source. Martin et al. (2010) reported that protozoa are largely responsible for methane production in the rumen ecosystem and some lipids, saponins, tannins and ionophores are toxic to protozoa. Newbold et al. (2004) has shown that methane production has reduced by almost $50 \%$ by removal of protozoa from rumen depending on the feed administered.

A great variety of secondary compounds (saponins, organosulphurs, gingerol, flavonoids, alkalois and tannins) are produced by plants to provide protection against any kind of attack (Iason, 2005). These compounds have been shown to exert specific effect against rumen protozoa while leaving the rest of the rumen biomass unaltered (Wang et al., 2000).

\section{Essential oils}

Essential oils are volatile, aromatic compounds extracted from plants by solvent extraction or pressure extraction under liquid carbon dioxide, steam distillation (Greathead, 2003). They are a variable mixtures terpenoids and a variety of low molecular weight aliphatic hydrocarbons, acids, alcohols, aldehydes, acyclic esters or lactones, and sometimes $\mathrm{N}$ - and S-containing compounds, coumarins, and homologues of phenylpropanoids (Dorman \& Deans, 2000). They have been shown to exhibit antimicrobial properties against different types of microorganisms including bacteria, protozoa, and fungi (Helander et al., 1998, Greathead, 2003, Busquet et al., 2006, Macheboeuf et al., 2008).

The main effects of essential oils in the rumen include reduction of protein and starch degradation and inhibition of amino acid degradation, due to selective action on certain rumen microorganisms, especially some bacteria (Yildiz et al., 2015). It has been reported that they affect rumen bacterial colonization especially in starch rich substrates and inhibition of hyper ammonia producing bacteria involved in amino acid deamination (Hart et al., 2008). The main antimicrobial mechanisms of 
essential oils are on cell membrane (Calsamiglia et al., 2007) affecting electron transport, ion gradients, protein translocation, phosphorylation steps, and other enzyme-dependent reactions (Ultee et al., 2000, Dorman \& Deans, 2000, Ultee et al., 1999). Chao et al. (2000) have reported that Gramnegative bacteria tended to have a higher resistance to essential oils than Gram-positive bacteria due to the barrier of the cell wall structure not tolerating the inflow of the secondary metabolites easily. A lot of successes have been achieved by researcher on using essential oils to improve rumen fermentation, inhibition of methanogenesis, improve metabolism of protein and feed utilization efficiency (Patra, 2011, Baraka \& Abdl-Rahman, 2012).

Table 1. Results from different articles using plant extracts and essential oil on rumen microorganisms and observations

\begin{tabular}{|c|c|c|}
\hline $\begin{array}{l}\text { Name of } \\
\text { Authors }\end{array}$ & Title of the research & Outcome with respect to rumen microbes and products \\
\hline$\frac{\text { Wang et al. }}{(2000)}$ & $\begin{array}{l}\text { Effect of steroidal saponin } \\
\text { from Yucca } \\
\text { extract } \text { schidigera } \\
\text { microbes }\end{array}$ & $\begin{array}{l}\text { Steroidal saponin isolated from Yucca schidigera repeantedly and substantially } \\
\text { depressed the activity of cellulolytic ruminal bacteria and fungi whereas its effect } \\
\text { on the non-cellulolytic ruminal bacteria examined were variable and species } \\
\text { dependent. } \\
\text { Among the four non-cellulolytic species examined in their study, bacterial } \\
\text { responses included prolonged lag time (Prevotella bryantii and Streptococcus } \\
\text { bovis), increased cell lysis subsequent to attainment of stationary phase (Prevotella } \\
\text { bryantii and Ruminobacter amylophilus) and, extensive growth prior to stationary } \\
\text { phase (Selenomonas ruminantium). } \\
\text { All the Gram-positive bacteria examined were inhibited in this trial, whereas the } \\
\text { Gram-negative species were unaffected. }\end{array}$ \\
\hline$\frac{\text { McIntosh et }}{\text { al. }(2003)}$ & $\begin{array}{l}\text { Effects of essential oils on } \\
\text { ruminal microorganisms } \\
\text { and their protein } \\
\text { metabolism }\end{array}$ & $\begin{array}{l}\text { The research demonstrated that commercial blend of essential oil compounds } \\
\text { containing thymol inhibited the growth of a specific group of ammonia hyper- } \\
\text { producing bacteria especially Clostridium stiklandii and Peptostreptococcus } \\
\text { anaerobius. Blend of essential oil had no effect on protozoans in vitro but } \\
\text { significantly decreased the growth of the anaerobic rumen fungus Neocallimastix } \\
\text { frontalis, } \\
\text { The research also found out that some pure strains of rumen bacteria could adapt to } \\
\text { growth in the presence of essential oil when introduced in a stepwise way by } \\
\text { increasing the essential oil concentrations. Bacteria did significantly differ in their } \\
\text { sensitivity to blend of essential oil as the growth of Clostridium sticklandii } \\
\text { decreased by } 50 \% \text { at a concentration of } 36 \mathrm{mg} / \mathrm{l} \text { while Streptococcus bovis growth } \\
\text { was unaffected until concentrations reached } 240 \mathrm{mg} / \mathrm{l} \text {. }\end{array}$ \\
\hline$\frac{\text { Patra et al. }}{(2006)}$ & $\begin{array}{l}\text { Effect of plant extracts on } \\
\text { in vitro methanogenesis, } \\
\text { enzyme activities and } \\
\text { fermentation of feed in } \\
\text { rumen liquor of buffalo }\end{array}$ & $\begin{array}{l}\text { Terminalia chebula, Acacia concinna and Azadirachta indica extracts resulted in a } \\
\text { significant reduction in protozoa count. Other extracts used had no influence on } \\
\text { total protozoal counts. Similar trends were observed for small and large } \\
\text { entodiniomorphid protozoa counts. } \\
\text { Holotrich protozoal were not affected by the extracts. }\end{array}$ \\
\hline $\begin{array}{l}\text { Benchaar et } \\
\text { al. }(2007)\end{array}$ & $\begin{array}{l}\text { Effects of essential oils } \\
\text { and their components on } \\
\text { in vitro rumen microbial } \\
\text { fermentation. }\end{array}$ & $\begin{array}{l}\text { Rumen Gram-negative bacteria were sensitive to carvacrol and eugenol while } \\
\text { Gram-positive bacteria were not. Carvacrol and eugenol also inhibited propionate- } \\
\text { producing bacteria and favoured butyrate-producing bacteria. } \\
\text { Inhibition of the growth of amylolytic bacteria accounts for reduction in the molar } \\
\text { proportion of propionate observed in the study. } \\
\text { None of the essential oil tested and compounds examined affected ammonia } \\
\text { concentration, suggesting that deaminative activity of ruminal bacteria was not } \\
\text { affected by essential oil and essential oil compounds. } \\
\text { Compounds Phenolics used in the study exhibit broad spectrum antimicrobial } \\
\text { activity against rumen microbes at high concentrations. }\end{array}$ \\
\hline $\begin{array}{l}\text { Fraser et al. } \\
(2007)\end{array}$ & $\begin{array}{l}\text { Assessment of the Effects } \\
\text { of cinnamon leaf oil on } \\
\text { rumen microbial } \\
\text { fermentation using two } \\
\text { continuous culture systems }\end{array}$ & $\begin{array}{l}\text { Protozoa numbers were found to decrease with the use of essential oil from } \\
\text { cinnamon (cinnamonum verum) leaf than with control in both the rumen simulation } \\
\text { technique (Rusitec) and dual-flow (DF) fermenter used. }\end{array}$ \\
\hline
\end{tabular}


Table 1. Collections of various results from different articles using plant extracts on rumen microorganisms and observations (Continuation)

\begin{tabular}{|c|c|c|}
\hline $\begin{array}{l}\text { Name of } \\
\text { Authors }\end{array}$ & Title of the research & Outcome with respect to rumen microbes and products \\
\hline$\underline{\text { Öztürk et }}$ & $\begin{array}{l}\text { Effects of olive leaf } \\
\text { extract on rumen } \\
\text { microbial fermentation in } \\
\text { in vitro semi-continuous } \\
\text { culture rem } \\
\text { (RUSITEC) }\end{array}$ & $\begin{array}{l}\text { There was significant decrease in the number of rumen ciliate protozoan while the } \\
\text { numbers of bacteria and starch degradation increase with reduction in } \mathrm{NH}_{3} \\
\text { production. Olive leaf (Olea europaea) extract inhibit the growth of both Gram } \\
\text { positive and Gram negative bacteria. }\end{array}$ \\
\hline$\frac{\text { Kim et al. }}{(2012)}$ & $\begin{array}{l}\text { Effects of plants extracts } \\
\text { on microbial population, } \\
\text { methane emission and } \\
\text { ruminal fermentation } \\
\text { characteristics in in vitro }\end{array}$ & $\begin{array}{l}\text { Worm wood (Artemisia absinthium), garlic (Alium sativum), onion (Alium cepa), } \\
\text { ginger (Zinginber officinalis), mandarin orange (Citrus reticulate), and honeysuckle } \\
\text { (Lonicera sempervirens) were the plant extracts used and they all decreased the } \\
\text { population of ciliate-associated methanogen, thereby, reducing methane emissions. } \\
\text { Garlic and ginger extracts were found to have decreased the protozoa population } \\
\text { resulting in reduction of methane emission in the rumen and thus inhibiting } \\
\text { methanogenesis. } \\
\text { The addition of wormwood, garlic, mandarin orange and honeysuckle extracts } \\
\text { increased the population of Fibrobacter succinogens in particular to a greater extent } \\
\text { than other fibrolytic microorganisms. } \\
\text { The Ruminococcus albus diversity in added onion extract increased, while other } \\
\text { extracts did not influence the R. albus community. } \\
\text { Ruminococcus flavefaciens population decreased with the addition of wormwood } \\
\text { and garlic extracts, but increased with the addition of other extracts. }\end{array}$ \\
\hline$\underline{\text { Patra \& Yu }}$ & $\begin{array}{l}\text { Effects of essential oils on } \\
\text { methane production and } \\
\text { fermentation by, and } \\
\text { abundance and diversity } \\
\text { of, rumen microbial } \\
\text { populations }\end{array}$ & $\begin{array}{l}\text { Total gas and methane production by the ruminal cultures decreased linearly with } \\
\text { increasing doses of all essential oils. All the essential oils decreased the abundance } \\
\text { of archaea, protozoa, and major cellulolytic bacteria (Fibrobacter succinogenes, } \\
\text { Ruminococcus flavefaciens, and R. albus) as determined by quantitative real-time } \\
\text { PCR. } \\
\text { On the basis of denaturing gradient gel electrophoresis analysis, different essential } \\
\text { oils changed the composition of both archaeal and bacterial communities to } \\
\text { different extents. }\end{array}$ \\
\hline 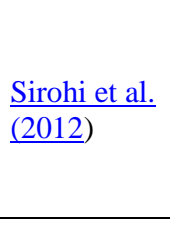 & $\begin{array}{l}\text { Efficacy of different } \\
\text { methanolic plant extracts } \\
\text { on anti-methanogenesis, } \\
\text { rumen fermentation and } \\
\text { gas production kinetics in } \\
\text { vitro }\end{array}$ & $\begin{array}{l}\text { Methanolic extracts of three plants, mehandi (Lawsonia inermis), jaiphal (Myristica } \\
\text { fragrans) and green chili (Capsicum annuum) were found to have no significant } \\
\text { effect on protozoan populations. }\end{array}$ \\
\hline$\frac{\text { Oskoueian }}{\text { et al. }(2013)}$ & 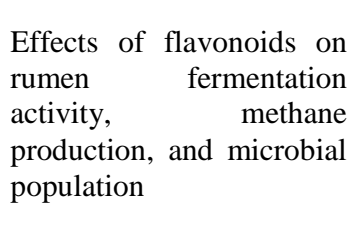 & $\begin{array}{l}\text { Addition of naringin and quercetin had no significant effects on the population of } \\
\text { bacteria, fungi, Fibrobacter succinogenes, Ruminococcus albus, and Ruminococcus } \\
\text { flavefaciens when compared to the control. } \\
\text { The flavonoids significantly suppressed the population of total protozoa and total } \\
\text { methanogens. The addition of flavone, myricetin, catechin, rutin, and kaempferol } \\
\text { significantly reduced the population of almost all of the rumen microorganism. }\end{array}$ \\
\hline$\frac{\text { Kim et al. }}{(2014)}$ & $\begin{array}{l}\text { Effects of coconut } \\
\text { materials on in vitro } \\
\text { ruminal methanogenesis } \\
\text { and fermentation } \\
\text { characteristics }\end{array}$ & $\begin{array}{l}\text { Researchers found out that coconut (Cocos nucifera) oil and coconut powder } \\
\text { decreased in the diversity of methanogens and ciliate-associated methanogens } \\
\text { compared to the treatment that has no addition of the oil and the powder. }\end{array}$ \\
\hline$\frac{\text { Yildiz et al. }}{(2015)}$ & $\begin{array}{l}\text { Determination of the } \\
\text { effects of some plant } \\
\text { extracts on rumen } \\
\text { fermentation and } \\
\text { protozoal counts by } \\
\text { Hohenheim in vitro gas } \\
\text { production technique }\end{array}$ & $\begin{array}{l}\text { Essence oils of Thymu vulgaris, Oreanum vulgare and Syzgium aromaticium tested } \\
\text { demonstrated antibacterial effects on in vitro conditions and lead to reduced } \\
\text { protozoal counts. } \\
\text { Zingiber officinale, compared to the positive and negative controls, had higher } \\
\text { protozoal while other essence oils had reduced protoazoal counts. }\end{array}$ \\
\hline
\end{tabular}




\section{Saponins}

Saponins are secondary compounds produced mainly by plants, but also by lower marine animals and some bacteria (Riguera, 1997, Yoshiki et al., 1998). They are natural detergents defined chemically as high-molecular-weight glycosides in which sugars are linked to a hydrophobic aglycone (sapogenic) which may be triterpenoid or steroidal in nature (Hart et al., 2008). The complex and diverse structures of saponin arise from the variability of the aglycon structure, the nature of the side chains and the attachment position of these moieties on the aglycone. Chwalek et al. 2004, Jung et al. 2004) have reported that the type of linkage and the composition of sugar of the saponin are related directly to their biological activity. They reduced protein degradation and favour microbial protein and biomass synthesis (Makkar et al., 1999), which resulted in reduced availability of hydrogen for $\mathrm{CH}_{4}$ production (Dijkstra et al., 2007). It has been reported that saponins tend to have dramatic effect on the activity of rumen protozoa (Teferedegne et al., 1999).

Saponins affect protozoa by forming complexes with sterols in the protozoal membrane surface (Wina et al., 2005). The membranes become impaired and ultimately disintegrate (Wallace et al., 2002). Fermentation in the rumen is also modified by suppression of rumen protozoa and selectively inhibiting some bacteria (Jayanegara et al., 2009). Thus, saponins rich plants have potential for enhancing flow of microbial protein from the rumen, increasing the efficiency of feed utilisation, and decreasing methanogenesis (Jayanegara et al., 2009).

\section{Organosulphurs}

Garlic (Allium sativum) has been used medicinally since ancient times in nearly every known civilization (Rivlin, 2006). Allium species contains many sulphur-containing compounds (Hart et al., 2008) produced from thiosulphates during the steam treatment of the plant (Pentz \& Siegers, 1996). The major sulphur-containing compounds in garlic are $\gamma$-glutamyl-S-allyl-Lcysteins and $S$-allyll- cysteine sulphoxides (alliin), which are converted into thiosulphinates (such as allicin) through enzymic reactions when raw garlic is cut or crushed (Stoll \& Seebeck, 1948). During processing of garlic, a broad range of different organosulphur compounds are produced which includes thiosulphinates, volatile organosulphurs and water-soluble organosulphurs (Iberl et al., 1990, Freeman \& Kodera, 1995, Kodera et al., 2002).

Garlic products are classified into four groups which are garlic essential oil, garlic oil macerate, garlic powder and garlic extract (Amagase, 2006). Due to the complexity of the chemical structure of garlic, their final concentration in each preparation varies significantly and also depends heavily upon the processing method used (Hart et al., 2008). The main antimicrobial effect is the ability to interact with the sulphydril groups (-SH) of other active compounds (Reuter et al., 1996) resulting in instability of the cell membrane of some specific microbial groups (Calsamiglia et al., 2007).

The main antimicrobial constituents of garlic have been tested in vitro to determine their effect on rumen microbial fermentation. Busquet et al. (2005) tested the effect of allicin, diallyl sulfide, diallyl disulfide and allyl mercaptan as well as garlic oil and found that garlic oil, diallyl disulphide and allyl mercaptan reduced acetate and methane while there was increase in propionate and butyrate concentrations. In contrast, allicin and diallyl sulfide had minor effects on rumen microbial fermentation (i.e the result of the direct inhibition of Archaea microorganisms in the rumen through the inhibition of HMG-CoA reductase (Calsamiglia et al., 2007, Kamel et al., 2008).

\section{Tannins}

Tannins are secondary plant compounds with various molecular weights (Jayanegara et al., 2012). They are found in cell walls, within vacuoles in stems, bark, leaves, flowers, or seeds in dicotyledonous plants (Archana et al., 2010). Based on their molecular structure they are classified into hydrolysable (polyesters of gallic acid and various sugars) and condensed tannins (polymers of flavonoids) (McSweeney et al., 2001). Frutos et al. (2004) described hydrolysable tannins as been made up of a carbohydrate core whose hydroxyl groups are esterified with phenolic acids (mainly gallic and hexahydroxydiphenic acid). Condensed tannins are non-branched polymers of flavonoids units (flavan-3-ol, flavan-3,4-diol) which usually have a higher molecular weight than hydrolysable tannins. It is believed that tannins decrease the rate 
of protein degradation in the rumen, slowed down the rates of both solubilisation and degradation of forage protein to ammonia (Patra \& Saxena, 2011).

The effects of tannins on ruminal bacteria are reported to be dependent upon the species of microorganism and type or source of tannin (Jones et al., 1994, Sivakumaran et al., 2004). It has been observed that the growth of proteolytic bacteria such as Butyrivibrio fibrisolvens, Ruminobacter amylophilus and Streptococcus bovis were reduced by condensed tannins of sainfoin (Onobrychis viciifolia) and had little effect on Prevotella ruminicola (Jones et al., 1994).

Tannins are also thought to suppress internal parasites and methanogenesis in ruminants (Patra \& Saxena, 2011, Jayanegara et al., 2012). The inhibitory effects of tannins on rumen methanogenesis have been attributed to their direct effects on methanogenic archaea and protozoa, indirectly leading to a depression of fibre degradation in the rumen (Patra \& Saxena, 2011). Wang et al. (2009) had shown that the addition of $0.5 \mathrm{~g} \mathrm{~L}^{-1}$ phlorotannins to rumen cultures inhibited the growth of Fibrobacter succinogenes, but had minimal effect on Ruminococcus flavefaciens and $R$. albus, whereas the growth of Selenomonas ruminantium, S. bovis, Ruminobacter amylophilus and Prevotella bryantii were stimulated.

Tannic acid had been demonstrated to inhibit cellulolysis and zoospore attachment to cellulose of the fungus Neocallimastix frontalis strain RE1 (Muhammed et al., 1995). The mechanisms of inhibition of rumen protozoa are not known (Patra \& Saxena, 2011), but tannins have been demonstrated to linearly increase the population of protozoal in rumen fluid of sheep fed with lucern hay (Salem et al., 1997). Benchaar et al. (2008b) did not observe any effect on protozoal numbers in dairy cattle fed quebracho tannins.

\section{Conclusion}

Different strategies have been explored to mitigate methane production using feed additives in ruminants. Plant extracts (essential oils, saponins, tannins and organosulphur compounds) have been exploited to manipulate rumen fermentation. Careful selection and combination of these additives may affect manipulation of protein degradation and methanogenesis in the rumen.
Effects of each extract is varied which is as a result of the concentration and nature of the active ingredient in the extract, diversity of forage available, intake, age of plant and other environmental influences. However, a universal extract that works under different conditions may not exist because effects are diet and $\mathrm{pH}$ dependent. All substances require more in vivo studies over a long period of time to determine whether the effect will be sustained. Successful implementation will also depend on the costeffectiveness and practicality in commercial farm systems.

\section{Conflict Interest}

There was no conflict interest among the authors.

\section{Acknowledgement}

This review was written when the first author was under the financial support of TWAS (The world Academy of Science) and CNPq (Conselho Nacional de Desenvolvimento Científico e Tecnological - Brazillian Scientific and Technological Development Council).

\section{References}

Amagase, H. (2006). Clarifying the real bioactive constituents of garlic. The Journal of Nutrition, 136, 716-725.

Archana, A. B., Jadhav, M. V. \& Kadam, V. J. (2010). Potential of tannins: a review. Asian Journal of Plant Sciences, 9, 209-214.

Baraka, T. A. M. \& Abdl-Rahman, M. A. (2012). In vitro evaluation of sheep rumen fermentation pattern after adding different levels of eugenolfumaric acid combinations. Veterinary World, $5,110-117$.

Benchaar, C., Calsamiglia, S., Chaves, A. V., Fraser, G. R., Colombatto, D., McAllister, T. A. \& Beauchemin, K. A. (2008a). A review of plant-derived essential oils in ruminant nutrition and production. Animal Feed Science and Technology, 145, 209-228.

Benchaar, C., Chaves, A. V., Fraser, G. R., Wang, Y., Beauchemin, K. A. \& McAllister, T. A. (2007). Effects of essential oils and their components on in vitro rumen microbial 
fermentation. Canadian Journal of Animal Science, 87, 413-419.

Benchaar, C., McAllister, T. A. \& Chouinard, P. Y. (2008b). Digestion, ruminal fermentation, ciliate protozoal populations, and milk production from dairy cows fed cinnamaldehyde, quebracho condensed tannin, or yucca schidigera saponin extracts. Journal of Dairy Science, 91, 4765-4777.

Busquet, M., Calsamiglia, S., Ferret, A., Carro, M. D. \& Kamel, C. (2005). Effect of garlic oil and four of its compounds on rumen microbial fermentation. Journal of Dairy Science, 88, 4393-4404.

Busquet, M., Calsamiglia, S., Ferret, A. \& Kamel, C. (2006). Plant extracts affect in vitro rumen microbial fermentation. Journal of Dairy Science, 89, 761-771.

Calsamiglia, S., Busquet, M., Cardozo, P. W., Castillejos, L. \& Ferret, A. (2007). Invited review: essential oils as modifiers of rumen microbial fermentation. Journal of Dairy Science, 90, 2580-2595.

Chao, S. C., Young, D. G. \& Oberg, C. J. (2000). Screening for inhibitory activity of essential opils on selected bacteria, fungi and viruses. Journal of Essential Oil Research, 12, 639-649.

Chwalek, M., Plé, K. \& Voutquenne-Nazabadioko, L. (2004). Synthesis and hemolytic activity of some hederagenin diglycosides. Chemical and Pharmaceutical Bulletin, 52, 965-971.

Cruz, O. T. B., Valero, M. V., Zawadzki, F., Rivaroli, D. C., Prado, R. M., Lima, B. S. \& Prado, I. N. (2014). Effect of glycerine and essential oils (Anacardium occidentale and Ricinus communis) on animal performance, feed efficiency and carcass characteristics of crossbred bulls finished in a feedlot system. Italian Journal of Animal Science, 13, 790-797.

Dehority, B. A. (2010). Physiological characteristics of several rumen protozoa grown in vitro with observations on within and among species variation. European Journal of Protistology, 46, 271-279.

Dijkstra, J., Bannink, A., France, J. \& Kebreab, E. (2007). Nutritional control to reduce environmental impacts of intensive dairy cattle systems. In: Meng, Q. X., Ren, L. P. \& Cao, Z. J. (eds.) Proceedings of the 7th International Symposium on the Nutrition of Herbivores.

Dorman, H. J. D. \& Deans, S. G. (2000). Antimicrobial agents from plants: antibacterial activity of plant volatile oils. Journal of Applied Microbiology, 88, 308-316.

Fraser, G. R., Chaves, A. V., Wang, Y., McAllister, T. A., Beauchemin, K. A. \& Benchaar, C. (2007). Assessment of the effects of cinnamon leaf oil on rumen microbial fermentation using two continuous culture systems. Journal of Dairy Science, 90, 2315-2328.

Freeman, F. \& Kodera, Y. (1995). Garlic chemistry: stability of S-(2-propenyl)-2propene-1-sulfinothioate (allicin) in blood, solvents, and simulated physiological fluids. Journal of Agricultural and Food Chemistry, 43, 2332-2338.

Frutos, P., Hervas, G., Giráldez, F. J. \& Mantecón, A. (2004). Review. Tannins and ruminant nutrition. Spanish Journal of Agricultural Research, 2, 191-202.

Geraci, J. I., Garciarena, A. D., Gagliostro, G. A., Beauchemin, K. A. \& Colombatto, D. (2012). Plant extracts containing cinnamaldehyde, eugenol and capsicum oleoresin added to feedlot cattle diets: Ruminal environment, short term intake pattern and animal performance. Animal Feed Science and Technology, 176, 123-130.

Goodland, R. \& Anhang, J. (2009). Livestock and climate change: What if the key actors in climate change are... cows, pigs, and chickens? World Watch, 22, 10-19.

Greathead, H. (2003). Plants and plant extracts for improving animal productivity. Proceedings of the Nutrition Society, 62, 279-290.

Hart, K. J., Yáñez-Ruiz, D. R., Duval, S. M., McEwan, N. R. \& Newbold, C. J. (2008). Plant extracts to manipulate rumen fermentation. Animal Feed Science and Technology, 147, 835.

Helander, I. M., Alakomi, H.-L., Latva-Kala, K., Mattila-Sandholm, T., Pol, I., Smid, E. J., Gorris, L. G. \& von Wright, A. (1998). Characterization of the action of selected 
essential oil components on Gram-negative bacteria. Journal of agricultural and food chemistry, 46, 3590-3595.

Iason, G. (2005). The role of plant secondary metabolites in mammalian herbivory: ecological perspectives. Proceedings of the Nutrition Society, 64, 123-131.

Iberl, B., Winkler, G. \& Knobloch, K. (1990). Products of allicin transformation: Ajoenes and dithiins, characterization and their determination by HPLC. Planta Medica, 56, 202-211.

Jayanegara, A., Leiber, F. \& Kreuzer, M. (2012). Meta analysis of the relationship between dietary tannin level and methane formation in ruminants from in vivo and in vitro experiments. Journal of Animal Physiology and Animal Nutrition, 96, 365-375.

Jayanegara, A., Togtokhbayar, N., Makkar, H. P. S. \& Becker, K. (2009). Tannins determined by various methods as predictors of methane production reduction potential of plants by in vitro rumen fermentation system. Animal Feed Science and Technology, 150, 230-237.

Jones, G., McAllister, T., Muir, A. \& Cheng, K.-J. (1994). Effects of sainfoin (Onobrychis viciifolia Scop.) condensed tannins on growth and proteolysis by four strains of ruminal bacteria. Applied and Environmental Microbiology, 60, 1374-1378.

Jung, H. J., Lee, C. O., Lee, K. T., Choi, J. \& Park, H. J. (2004). Structure-activity relationship of oleanane disaccharides isolated from Akebia quinata versus cytotoxicity against cancer cells and NO inhibition. Biological and Pharmaceutical Bulletin, 27, 744-747.

Kamel, C., Greathead, H. M. R., Tejido, M. L., Ranilla, M. J. \& Carro, M. D. (2008). Effects of allicin and diallyl disulfide on in vitro rumen fermentation of a mixed diet. Animal Feed Science and Technology, 145, 351-363.

Kim, E., Kim, C.-H., Min, K.-S. \& Lee, S. (2012). Effects of plant extracts on microbial population, methane emission and ruminal fermentation characteristics in in vitro. AsianAustralasian Journal of Animal Sciences, 25, 806-811.
Kim, E., Park, C., Lim, D., Kwon, E., Ki, K., Kim, S., Moon, Y., Shin, N. \& Lee, S. (2014). Effects of coconut materials on in vitro ruminal methanogenesis and fermentation characteristics. Asian-Australasian Journal of Animal Sciences, 27, 1721.

Kodera, Y., Suzuki, A., Imada, O., Kasuga, S., Sumioka, I., Kanezawa, A., Taru, N., Fujikawa, M., Nagae, S. \& Masamoto, K. (2002). Physical, chemical, and biological properties of S-allylcysteine, an amino acid derived from garlic. Journal of Agricultural and Food Chemistry, 50, 622-632.

Macheboeuf, D., Morgavi, D. P., Papon, Y., Mousset, J. L. \& Arturo-Schaan, M. (2008). Dose-response effects of essential oils on in vitro fermentation activity of the rumen microbial population. Animal Feed Science and Technology, 145, 335-350.

Makkar, H. P. S., Becker, K., Nitis, I. M. \& Shin, M. T. (1999). Plant toxins and detoxification methods to improve feed quality of tropical seeds. Asian-Australasian Journal of Animal Sciences, 12, 467-480.

Martin, C., Morgavi, D. P. \& Doreau, M. (2010). Methane mitigation in ruminants: from microbe to the farm scale. Animal, 4, 351-365.

McIntosh, F. M., Williams, P., Losa, R., Wallace, R. J., Beever, D. A. \& Newbold, C. J. (2003). Effects of essential oils on ruminal microorganisms and their protein metabolism. Applied and Environmental Microbiology, 69, 5011-5014.

McSweeney, C. \& Mackie, R. (2012). Microorganisms and ruminant digestion: state of knowledge, trends and future prospects. Background study paper. Roma.

McSweeney, C., Palmer, B., McNeill, D. \& Krause, D. (2001). Microbial interactions with tannins: nutritional consequences for ruminants. Animal Feed Science and Technology, 91, 8393.

Muhammed, S., Stewart, C. \& Acamovic, T. (1995). Effects of tannic acid, ellagic acid, gallic acid and catchin on cellulase degradation by the rumen fungus Neocallimastix frontalis strain RE1. Animal Science, 60, 550. 
Murray, R., Bryant, A. \& Leng, R. (19760. Rates of production of methane in the rumen and large intestine of sheep. British Journal of Nutrition, $36,1-14$.

Newbold, C. J., McIntosh, F. M., Williams, P., Losa, R. \& Wallace, R. J. (2004). Effects of a specific blend of essential oil compounds on rumen fermentation. Animal Feed Science and Technology, 114, 105-112.

Oskoueian, E., Abdullah, N. \& Oskoueian, A. (2013). Effects of flavonoids on rumen fermentation activity, methane production, and microbial population. BioMed Research International, 2013, 1-8.

Öztürk, H., Demirtaş, A., Salgırlı, Y., Pekcan, M., Emre, B. \& Fidanci, U. (2012). Effects of olive leaf extract on rumen microbial fermentation in in vitro semi-continuous culture system (RUSITEC). Ankara Üniversitesi Veteriner Fakültesi Dergisi, 59, 17-21.

Patra, A. K. (2011). Effects of essential oils on rumen fermentation, microbial ecology and ruminant production. Asian Journal of Animal Veterinary Advances, 6, 416-428.

Patra, A. K., Kamra, D. N. \& Agarwal, N. (2006). Effect of plant extracts on in vitro methanogenesis, enzyme activities and fermentation of feed in rumen liquor of buffalo. Animal Feed Science and Technology, 128, 276-291.

Patra, A. K. \& Saxena, J. (2010). A new perspective on the use of plant secondary metabolites to inhibit methanogenesis in the rumen. Phytochemistry, 71, 1198-1222.

Patra, A. K. \& Saxena, J. (2011). Exploitation of dietary tannins to improve rumen metabolism and ruminant nutrition. Journal of the Science of Food and Agriculture, 91, 24-37.

Patra, A. K. \& Yu, Z. (2012). Effects of essential oils on methane production and fermentation by, and abundance and diversity of, rumen microbial populations. Applied and Environmental Microbiology, 78, 4271-4280.

Pentz, R. \& Siegers, C. (1996). Methods for qualitative and quantitative assessment of their ingredients. Garlic: the science and therapeutic application of Allium sativum L. and related species. Baltimore: Williams \& Wilkins, 109134.

Prado, I. N., Cruz, O. T. B., Valero, M. V., Zawadski, F., Eiras, C. E., Rivaroli, D. C., Prado, R. M. \& Visentainer, J. V. (2016). Effects of glycerin and essential oils (Anacardium occidentale and Ricinus communis) on the meat quality of crossbred bulls finished in a feedlot. Animal Production Science, in press.

Reuter, H. D., Koch, H. P. \& Lawson, L. D. (1996). Therapeutic effects and applications of garlic and its preparations. The Science and Therapeutic Application of Allium sativum L. and Related Species, 135-212.

Riguera, R. (1997). Isolating bioactive compounds from marine organisms. Journal of Marine Biotechnology, 5, 187-193.

Rivlin, R. S. (2006). Is garlic alternative medicine? The Journal of Nutrition, 136, 713-715.

Russell, J. B. \& Houlihan, A. J. 2003. Ionophore resistance of ruminal bacteria and its potential impact on human health. FEMS Microbiology Reviews, 27, 65-74.

Salem, H. B., Nefzaoui, A., Salem, L. B. \& Tisserand, J. (1997). Effect of Acacia cyanophylla Lindl. foliage supply on intake and digestion by sheep fed lucerne hay-based diets. Animal Feed Science and Technology, 68, 101113.

Sirohi, S. K., Goel, N. \& Pandey, P. (2012). Efficacy of different methanolic plant extracts on anti-methanogenesis, rumen fermentation and gas production kinetics in vitro. Open Veterinary Journal, 2, 72-77.

Sivakumaran, S., Molan, A. L., Meagher, L. P., Kolb, B., Foo, L. Y., Lane, G. A., Attwood, G. A., Fraser, K. \& Tavendale, M. (2004). Variation in antimicrobial action of proanthocyanidins from Dorycnium rectum against rumen bacteria. Phytochemistry, 65, 2485-2497.

Stoll, A. \& Seebeck, E. (1948). Allium compounds. I. Alliin the true mother compound of garlic oil. Helvetica Chimical Acta, 31, 189-210. 
Teferedegne, B., McIntosh, F., Osuji, P. O., Odenyo, A., Wallace, R. J. \& Newbold, C. J. (1999). Influence of foliage from different accessions of the sub-tropical leguminous tree, Sesbania sesban, on ruminal protozoa in Ethiopian and Scottish sheep. Animal Feed Science and Technology, 78, 11-20.

Tomkins, N. W., Denman, S. E., Pilajun, R., Wanapat, M., McSweeney, C. S. \& Elliott, R. (2015). Manipulating rumen fermentation and methanogenesis using an essential oil and monensin in beef cattle fed a tropical grass hay. Animal Feed Science and Technology, 200, 2534.

Ultee, A., Kets, E. P. W., Alberda, M., Hoekstra, F. A. \& Smid, E. J. (2000). Adaptation of the food-borne pathogen Bacillus cereus to carvacrol. Archives of Microbiology, 174, 233238.

Ultee, A., Kets, E. P. W. \& Smid, E. J. (1999). Mechanisms of action of carvacrol on the foodborne pathogen Bacillus cereus. Applied and Environmental Microbiology, 65, 4606-4610.

Valero, M. V., Prado, R. M., Zawadzki, F., Eiras, C. E., Madrona, G. S. \& Prado, I. N. (2014a). Propolis and essential oils additives in the diets improved animal performance and feed efficiency of bulls finished in feedlot. Acta Scientiarum. Animal Sciences, 36, 419-426.

Valero, M. V., Torrecilhas, J. A., Zawadzki, F., Bonafé, E. G., Madrona, G. S., Prado, R. M., Passetti, R. A. C., Rivaroli, D. C., Visentainer, J. V. \& Prado, I. N. (2014b). Propolis or cashew and castor oils effects on composition of Longissimus muscle of crossbred bulls finished in feedlot. Chilean Journal of Agricultural and Research, 74, 445-451.

Wallace, R. J., McEwan, N. R., McIntosh, F. M., Teferedegne, B. \& Newbold, C. J. 2002. Natural products as manipulators of rumen fermentation. Asian Australasian Journal of Animal Sciences, 15, 1458-1468.

Wanapat, M., Kang, S. \& Polyorach, S. (2013). Development of feeding systems and strategies of supplementation to enhance rumen fermentation and ruminant production in the tropics. Journal of Animal Science and Biotechnology, 4, 1-11.

Wang, C. J., Wang, S. P. \& Zhou, H. (2009). Influences of flavomycin, ropadiar, and saponin on nutrient digestibility, rumen fermentation, and methane emission from sheep. Animal Feed Science and Technology, 148, 157-166.

Wang, Y., McAllister, T., Yanke, L. \& Cheeke, P. (2000). Effect of steroidal saponin from Yucca schidigera extract on ruminal microbes. Journal of Applied Microbiology, 88, 887-896.

Wina, E., Muetzel, S. \& Becker, K. (2005). The impact of saponins or saponin-containing plant materials on ruminant production: A Review. Journal of Agricultural and Food Chemistry, 53, 8093-8105.

Yildiz, G., Tekeli, A., Drochner, W. \& Steingass, H. (2015). Determination of the effects of some plant extracts on rumen fermentation and protozoal counts by hohenheim" in vitro" gas production Technique. International Journal of Animal and Veterinary Advances, 7, 18-26.

Yoshiki, Y., Kudou, S. \& OKuBo, K. (1998). Relationship between chemical structures and biological activities of triterpenoid saponins from soybean. Bioscience, Biotechnology, and Biochemistry, 62, 2291-2299.

Zawadzki, F., Prado, I. N., Marques, J. A., Zeoula, L. M., Rotta, P. P., Sestari, B. B., Valero, M. V. \& Rivaroli, D. C. (2011). Sodium monensin or propolis extract in the diets of feedlot-finished bulls: effects on animal performance and carcass characteristics. Journal of Animal and Feed Sciences, 20, 16-25.

Received in January 212016

Accepted in February 22, 2016

License information: This is an open-access article distributed under the terms of the Creative Commons Attribution License, which permits unrestricted use, distribution, and reproduction in any medium, provided the original work is properly cited 